\title{
COMMENTARY
}

\section{Are arterial blood gases necessary in the evaluation of acutely dyspneic patients?}

\author{
Christopher Junker ${ }^{\text {** }}$ and Guillermo Gutierrez ${ }^{2}$ \\ See related research by Burri et al., http://ccforum.com/content/15/3/R145
}

\begin{abstract}
Arterial blood gases (ABG) are obtained commonly

in dyspneic persons presenting to emergency

departments. The study by Burri and colleagues

found that the information contained in ABG fails to

distinguish between pulmonary and other causes of

dyspnea. On the other hand, arterial pH was highly

predictive of ICU admission and outcome. Until large

clinical studies show equivalence between peripheral

venous and $A B G$, we will continue to advocate the use

of $A B G$ in the evaluation of acute dyspnea.
\end{abstract}

The recent study by Burri and colleagues examined the usefulness of arterial blood gases (ABG) in the diagnosis and prognosis of 530 dyspneic patients with $\mathrm{ABG}$ drawn upon presentation to the emergency department [1]. The study was a retrospective analysis of prospectively collected data performed at a single center. They concluded that ABG cannot be used to distinguish between pulmonary and other causes of dyspnea.

Prior to the introduction of automated blood gas analyzers, blood $\mathrm{PO}_{2}$ and $\mathrm{PCO}_{2}$ could be obtained only by laborious and often inaccurate laboratory methods, such as gas tonometry and Van Slyke manometric extraction of plasma total carbon dioxide. Improvements in electrode technology came with the development of the Astrup $\mathrm{pH}$ electrode [2], the Stow/Severinghaus-type $\mathrm{PCO}_{2}$ electrode $[3,4]$ and the polarographic oxygen Clark electrode [5]. Although pulse oximetry has largely superseded the use of arterial $\mathrm{PO}_{2}\left(\mathrm{PaO}_{2}\right)$, the ease by which ABG can now be measured has made this test de rigueur in the workup of dyspneic patients.

*Correspondence: cjunker@mfa.gwu.edu

'Department of Anesthesiology and Critical Care Medicine, The George

Washington University MFA, 2150 Pennsylvania Ave, NW, Washington, DC 20037,

USA

Full list of author information is available at the end of the article
We agree with Burri and colleagues in that $\mathrm{PaO}_{2}$ values serve mainly to triage and to guide treatment, rather than to differentiate among the causes of dyspnea. Except for anxiety hyperventilation, it is difficult to rely solely on ABG to identify a specific clinical syndrome. This is not new information. The poor predictive value of $\mathrm{PaO}_{2}$ in diagnosing patients with pulmonary embolism is well known. In the PIOPED I study of patients with angiographically proven pulmonary embolism and no prior cardiopulmonary disease, $26 \%$ had $\mathrm{PaO}_{2}>80 \mathrm{mmHg}$ [6]. This figure was $38 \%$ in the PIOPED II study $(n=42)[7,8]$. The probability of diagnosing an acute pulmonary embolism based on changes in $\mathrm{PaO}_{2}$ did not achieve statistical significance. Further, no combination of $\mathrm{PO}_{2}$ and $\mathrm{PCO}_{2}$ values could reliably exclude pulmonary embolism.

Burri and colleagues also report that arterial $\mathrm{pH}$ was a significant predictor of short-term and long-term outcome. Multiple physiological buffers act to preserve the concentration of hydrogen ions in blood within a relatively small range. Decreases in arterial $\mathrm{pH}$ are likely to reflect severe impairments or even exhaustion of systemic compensatory mechanisms in patients with acute dyspnea. The predictive value of the arterial $\mathrm{pH}$ in dyspneic patients noted by Burri and colleagues supports this hypothesis.

Burri and colleagues propose the use of venous blood $\mathrm{pH}$ in the initial evaluation of acute dyspnea, based on data from several single-center studies reporting relatively close limits of agreement $(-0.11$ to +0.04$)$ between arterial $\mathrm{pH}$ and venous blood $\mathrm{pH}[9,10]$. One must keep in mind, however, that muscular activity or regional microcirculatory alterations could result in misleadingly low regional $\mathrm{pH}$ values in septic or agitated patients.

Substituting venous blood $\mathrm{pH}$ for arterial $\mathrm{pH}$ in the evaluation of dyspneic patients is an appealing notion, but one that requires testing in multicenter, prospective clinical studies. Until these studies corroborate the equivalence between arterial and peripheral venous blood gases, or until non-invasive techniques to monitor arterial $\mathrm{PCO}_{2}$ and $\mathrm{pH}$ become available, we shall continue to support the use of ABG in the initial evaluation and treatment of patients with acute dyspnea. 


\section{Abbreviations}

ABG, arterial blood gases; ICU, intensive care unit; $\mathrm{PaCO}_{2}$, arterial partial pressure of carbon dioxide; $\mathrm{PCO}_{2}$, partial pressure of carbon dioxide; $\mathrm{PO}_{2}$ partial pressure of oxygen.

\section{Competing interests}

The authors declare that they have no competing interests.

\section{Author details}

'Department of Anesthesiology and Critical Care Medicine, The George Washington University MFA, 2150 Pennsylvania Ave, NW, Washington,

DC 20037, USA. 'Department of Medicine and Anesthesiology, Division of Pulmonary and Critical Care Medicine, The George Washington University MFA, 2150 Pennsylvania Ave, NW, Washington, DC 20037, USA.

Published: 2 August 2011

\section{References}

1. Burri E, Potocki M, Drexler B, Schuetz P, Mebazaa A, Ahlfeld U, Balmelli C, Heinisch C, Noveanu M, Breidthardt T, Schaub N, Reichlin T, Mueller C: Value of arterial blood gas analysis in patients with acute dyspnea: an observational study. Crit Care 2011, 15:R145.

2. Astrup P, Schrøder S: Apparatus for anaerobic determination of $\mathrm{pH}$ in blood. Scand J Clin Invest 1956, 8:30-32.

3. Stow RW, Baer RF, Randall B: Rapid measurement of the tension of carbon dioxide in blood. Arch Phys Med Rehabil 1957, 38:646-650.

4. Severinghaus JW, Bradley AF: Electrodes for blood $\mathrm{PO}_{2}$ and $\mathrm{PCO}_{2}$ determination. J Appl Physiol 1958; 13:515-520.

5. Clark LC Jr: Monitor and control of blood and tissue oxygen tensions. Trans Am Soc Artif Intern Organs 1956, 2:41-48.

6. PIOPED Investigators: Value of the ventilation/perfusion scan in acute pulmonary embolism. Results of the prospective in vestigation of pulmonary embolism diagnosis (PIOPED). JAMA 1990, 263:2753-2755.

7. Stein PD, Fowler SE, Goodman LR, Gottschalk A, Hales CA, Hull RD, Leeper KV Jr, Popovich J Jr, Quinn DA, Sos TA, Sostman HD, Tapson VF, Wakefield TW Weg JG, Woodard PK: PIOPED II Investigators: Multidetector computed tomography for acute pulmonary embolism. NEng/ J Med 2006, 354:2317-2327.

8. Stein PD, Beemath A, Matta F, Weg JG, Yusen RD, Hales CA, Hull RD, Leeper KV Jr, Sostman HD, Tapson VF, Buckley JD, Gottschalk A, Goodman LR, Wakefied TW, Woodard PK: Clinical characteristics of patients with acute pulmonary embolism: data from PIOPED II. Am J Med 2007, 120:871-879.

9. Kelly AM, MCAlpine R, Kyle E: Venous $\mathrm{pH}$ can safely replace arterial $\mathrm{pH}$ in the initial evaluation of patients in the emergency department. Emerg Med J 2001, 18:340-342.

10. Treger R, Pirouz S, Kamangar N, Corry D: Agreement between central venous and arterial blood gas measurements in the intensive care unit. Clin J Am Soc Nephrol 2010, 5:390-394.

doi:10.1186/cc10279

Cite this article as: Junker C, Gutierrez G: Are arterial blood gases necessary in the evaluation of acutely dyspneic patients? Critical Care 2011, 15:176. 